\title{
Turist Rehberliği Saha Denetlemelerinde Karşılaşılan Uygunsuzlukların Önceliklerinin Pareto Analizi ile Belirlenmesi
}

\section{Determining the Priorities of Nonconformities Encountered in Tourist Guidance Field Inspections by Pareto Analysis}

\author{
Dr. Öğr. Üyesi Mehmet BAHAR \\ Kapadokya Üniversitesi, Kapadokya Meslek Yüksekokulu, Türkiye \\ Cappadocia University, Cappadocia Vocational School, Turkey \\ E-Mail: mehmet_bahar@kapadokya.edu.tr \\ Öğr. Gör. Emrullah CANSU \\ Kapadokya Üniversitesi, Kapadokya Meslek Yüksekokulu, Türkiye \\ Cappadocia University, Cappadocia Vocational School, Turkey \\ E-Mail: emrullahcansu58@gmail.com
}

$\ddot{O} z$

Amaç ve Önem: Bu çalışmanın amacı 2019 yılı Türkiye Turist Rehberleri Birliği (TUREB) rehberlik denetimlerinin incelenerek, hangi konularda daha çok yasadışı faaliyet gerçekleştirildiğini ortaya koymaktır. Bu çalışmanın gerekliliği ve önemi ise turist rehberliği mesleğinin önemini arttırıp, nitelikli bir meslek dalı olması için yapılan denetimlerin sonuçlarının değerlendirilip, akademik ve idari birimlere gerekli önerilerin sunulması ihtiyacından gelmektedir.

Yöntem: Bunun sağlanabilmesi için 2019 yllı Türkiye Turist Rehberleri Birliği (TUREB) saha denetimi raporları "Pareto Analizi" yöntemi ile incelenmiştir.

Bulgular: Araştırmada elde edilen bulguların bazılarına bakıldığında, 2019 yılı içinde toplam 1.317 adet denetleme gerçekleştirildiği görülmektedir. Bu denetlemelerin 264 adeti sadece Nisan ayında gerçekleştirilmiş olmasına rağmen takip eden aylarda bu rakamın çok altından yarıya yakın miktarda gerçekleştirildiği görülmektedir. 2019 yılında yapılan denetlemeler de 17 farklı konuda 1417 uygunsuzluk tespit edilmiş ve tutanak tutulmuştur. 2019 yılında gerçekleştirilen denetlemelerde karşılaşılan en büyük kusur 472 kez 'Belgesiz Acentecilik Faaliyetinde Bulunmak' ki bu da toplam denetlemelerin \%33'ünü oluşturmaktadır. İkinci sırada 386 kez 'Rehbersiz Tur Faaliyeti' yer almakta olup, bu da toplam denetlemelerin \%27'sini oluşturmaktadır. Üçüncü sırada ise 274 kez ile 'Kaçak Rehberlik Faaliyeti' toplam denetlemelerdeki \%19 payıyla yer almaktadır. Bu ilk üç en çok ihlal edilen madde toplandığında, 1132 ihlal ve toplam denetlemelerin yaklaşık \%80'inini oluşturmaktadır.

Özgünlük/Bilimsel Katkı: Araştırma öncelikle turist rehberliği mesleğindeki denetimlerin sonuçlarının bilimsel açıdan incelenip, ortaya çıkartılan sorunlar için sunulan önerilerle mesleğe katkı sağlamaktadır. Ayrıca akademik olarak turist rehberliği alanındaki literatürü de zenginleştirmektedir.

Anahtar Kelimeler: Turizm, turist rehberliği, denetim, TUREB, TÜRSAB.

Makale Türü: Araştırma makalesi

\section{Abstract}

Purpose and Importance: The purpose of this study is to examine the 2019 Turkey Tourist Guide Associations (TUREB) guidance audits and to reveal on which subjects more illegal activities were carried out. The necessity and importance of this study comes from the need to evaluate the results of

Atıf için (for cited); Bahar, M. ve Cansu, E. (2020). Turist Rehberliği Saha Denetlemelerinde Karş1laş1lan Uygunsuzlukların Önceliklerinin Pareto Analizi ile Belirlenmesi, Turist Rehberliği Dergisi, 3(2), 90-100.

* Bu çalışma, I. Conference on Managing Tourism Across Continents'de sözlü olarak sunulan bildirinin geliştirilmiş halidir. 
Turist Rehberliği Dergisi (TURED) \& Y1l. 2020, Cilt. 3, Sayı. 2

Journal of Tour Guiding (JOTOG) \& Year. 2020, Volume. 3, Issue. 2

the inspections made in order to increase the importance of the tourist guiding profession and to make it a qualified profession, and to present the necessary suggestions to the academic and administrative units.

Methodology: In order to achieve this, 2019, Turkey Tourist Guide Associations (TUREB) field audit reports were examined with the "Pareto Analysis" method.

Findings: Looking at some of the findings of the research, it is seen that a total of 1,317 inspections were carried out in 2019. Although 264 of these inspections were carried out only in April, it is seen that in the following months, this figure was realized at a much lower than half. During the inspections conducted in 2019, 1417 nonconformities in 17 different subjects were detected and report were kept. The biggest flaw encountered in the audits carried out in 2019 is 472 times 'Having an Undocumented Agency Activity', which constitutes $33 \%$ of the total inspections. In the second place, there is "No Guide Tour Activity" 386 times, which constitutes $27 \%$ of the total inspections. In the third place, "Illegal Guidance Activity" ranks 274 times with a share of $19 \%$ in total audits. When these top three most violated items are collected, they constitute about $80 \%$ of 1132 violations and total inspections.

Originality/Value: The research primarily contributes to the profession by examining the results of the inspections in the tourist guiding profession scientifically and with suggestions for the problems revealed. It also enriches the literature in the field of tourist guidance academically.

Keywords: Tourism, tourist guidance, inspection, TUREB, TURSAB.

Paper Type: Research article

\section{Giriş}

Turizm dünya ülkeleri arasında barışı sağlayan bir kilit olmakla birlikte aynı zamanda ekonomik olarak önemli bir sektör haline gelmiştir. Ülkeler turizmin ekonomik değer oluşturma potansiyelinden yararlanmak için gitgide turizm aktivitelerini arttırmaktadır (Bayram, 2016: 136-137). Bu turizm aktiviteleri arasında en çok pazar payına sahip olmak isteyen ülkeler bu noktada Turist Rehberlerine oldukça önem vermektedir. Çünkü turist rehberleri ülkelerine gelen yabancı turistleri ilk olarak karşılayan, istedikleri yabancı dillerde gezdiren, onlara tur programları başlangıcından bitişine kadar rehberlik edip, onlarla iletişim kuran, turistlere yardımcı olan ve gezdirdikleri yerlerin doğal ve kültürel miraslarını anlatıp, ülkelerini tanıtmada hayati rol oynayan kişilerdir (Avcı \& Doğan, 2017: 134). Ayrıca turizm amaçlı seyahatlerde en çok tercih edilen seyahat şekillerinden biri paket tur satın alıp toplu olarak yapılan seyahatlerdir (Cansu ve Bahadır, 2019). Bu amaçlı seyahatlerde çoğunlukla günlük turlar ve daha uzun süreli paket turların gerçekleştirilmesinde rehberler önemli rol oynarlar. Turist rehberlerinin nitelikli kişiler olması için eğitimi bu açıdan oldukça önemlidir. Osmanlı döneminden başlayarak günümüze kadar, rehberlik mesleği ihtiyaç duyulması halinde eğitim verilen bir meslek dalıydı. Ancak 2012 yılında çıkartılan 6326 sayılı Turist Rehberliği Meslek Kanunu ile yasal bir mevzuata kavuşmuş ve artık önemli sayılan meslek dallarından biri olmuştur (Yenipınar \& Zorkirişci, 2013: 120-123).

Yukarıda anlatılanlar ışı̆̆ında turist rehberliği mesleği birçok sorunla karşılaşmaktadır. Bunlar yapılan denetimler sonucunda ortaya çıkartılmaktadır. Bu bağlamda çalışmanın amacı 2019 yılı TUREB rehberlik denetimlerinin incelenerek, hangi konularda daha çok yasadışı faaliyet gerçekleştirildiğini ortaya koymaktır. Bu çalışmanın gerekliliği ise turist rehberliği mesleğinin önemini arttırıp, nitelikli bir meslek dalı olması için yapılan denetimlerin sonuçlarının değerlendirilip, akademik ve idari birimlere gerekli önerilerin sunulması ihtiyacından gelmektedir. Bunun sağlanması için 2019 yılı TUREB saha denetimi raporları "Pareto Analizi" yöntemi ile incelenmiştir. 
Turist Rehberliği Dergisi (TURED) \& Y11. 2020, Cilt. 3, Sayı. 2

Journal of Tour Guiding (JOTOG) \& Year. 2020, Volume. 3, Issue. 2

\section{Kavramsal Çerçeve}

Zaman Dünya Turist Rehberleri Birliği Federasyonunun tanımına göre, ülkelerine gelen ziyaretçilere kendi seçtikleri yabancı dilde anlatım yapan, ülkesinde uygun otorite yetkilerine sahip ve ziyaret edecekleri bölgelere özgü nitelikleri olup, kültürel ve doğal miraslarını yorumlayan kimselere turist rehberi denilmektedir. (WFTGA, 2020).

Turist rehberi olabilmek için gerekli şartlar 22.06.2012 yılında çıkan 6326 sayılı Turist Rehberliği Meslek Kanunu'nda açıkça belirtilmiştir. Bu şartlar arasında, T.C. vatandaşı olmak, 18 yaşını doldurmuş olmak, üniversitelerin turist rehberliği önlisans, lisans veya yüksek lisans bölümlerinden mezun olmak veya bakanlığın açacağı sertifika programını tamamlamak ve sonrasında Bakanlık aracılığıyla yapılan Uygulama (Eğitim) Gezilerine katılıp en az 1 yabancı dil sınavından başarı sağlamak vardır (Turist Rehberliği Meslek Kanunu, 2012).

Turist rehberlerinde fiziksel görünüşe önem vermenin dışında sabır, anlayış, liderlik, mizah kabiliyeti, kararlılık, mesleki etik gibi bazı unsurlar bulunmaktadır. Bunların dışında ülkelerine gelen turistleri karşıladıkları ve ülkelerini temsil ettikleri için büyük sorumlulukları olmasından dolayı iyi bir eğitim almaları da şarttır (İşçeli \& Kılıç, 2018: 44). Ancak bu eğitimden önce turist rehberi adayının mesleğe ilgi duyması, seyahat etmeyi, doğayı, ülkesinin kültürünü, konuşmayı, anlatmayı, okumayı seviyor olması gerekir (Çınar \& Yenipınar, 2019: 154). Bütün bunların yanı sıra bir turist rehberi sosyolojik ve psikolojik anlamda da bilgi sahibi olmalıdır. Grubunun psikolojisi, dinamiği, motivasyonu gibi unsurları görebilmeli ve bu durumları yönetebilmelidir (Pelit \& Katırcıoğlu, 2018: 76-77).

Turist rehberleri yalnızca turistik turlarda liderlik eden kişilerden ibaret değildir. Aynı zamanda ülkelerine gelen misafirleri ilk karşılayan ve ülkelerini tanıtmada en önemli rolleri olan meslek sahibi kişilerdendir (İrigüler \& Güler, 2016: 203). İlaveten bölgelerdeki turistik aktivitelerin arttırılmasında, turistler ve onların etkileşime geçtiği kiş̧ilerle olumlu iletişimi sağlamalarında, ülkelerindeki kültürel ve doğal mirasların sürdürülebilirliğinde önemli ölçüde etkileri olan kişilerdir (Tătar, Herman \& Gozner, 2018: 283). Türk turizmi açısından bakıldığından ise en iyi reklam yapan kişiler olarak turist rehberleri gelebilir. Ülkeye gelen turistleri, gezdikleri yerleri cazibeli kılıp, olumlu yorum ve anlatımlarla ülkenin imajını da yükseltmiş olur. İlaveten, turizm alanında farkındalık yaratıp, ülkenin turizm aktivitelerini arttırmada ve onları korumada öncü rol oynar. Ancak bunları yapabilmek için bir turist rehberinde uzmanlık, yeterli bilgi ve beceri de olması gerekmektedir (Arat \& Bulut, 2019: 34). Bunların sağlanabilmesi için de turist rehberliği için önemli ihtiyaçlardan biri olarak eğitimi gösterebiliriz. Türkiye'de bu eğitim 1925 yılında yürürlüğe giren Ecnebi Seyyahlara Tercümanlık ve Rehberlik Edecekler Hakkında Kararname ile ilk kez düzenlenmiştir. Daha sonra yıllarca çeşitli kararnameler ile düzenlemeler yapılmıştır. 1928 yılında İstanbul İktisat Müdürlüğü tarafından açılan rehberlik kursu ile 50 tercüman rehber mezun edilmiştir. Sonrasında ise 1950'li yıllarda turizm ve rehberlik mesleği önem kazanmış ve böylelikle 19531970 yılları arasında rehberlik kursları açılmıştır. Turist Rehberliği ile ilgili ilk yönetmelik ise 3 Eylül 1971 yılında yayınlanan 13945 sayılı Tercüman Rehber Kursları ve Tercüman Rehber Yönetmeliğidir. Bu yönetmelik birçok isim değişerek 2012 yılına kadar çeşitli düzenleme ve değişikliklerle süregelmiştir (Albuz, Çakmak, Eren, Tekin \& Yeşildağ, 2018: 84-85). 22 Haziran 2012 yılında Resmî Gazetede çıkan 28331 sayılı Turist Rehberliği Meslek Kanunu yayınlanmıştır. Sonrasında 26 Aralık 2014 tarihinde Profesyonel Turist Rehberliği Yönetmeliği düzenlenip, yayınlanmıştır. Günümüzde turist rehberliği eğitimi de yine bu kanun ve yönetmeliğe bağlı olarak verilmektedir (Turist Rehberliği Meslek Yönetmeliği, 2014).

Turist Rehberlerinin meslekten beklentileri bulunmaktadır. Bu beklentilerin başında olumlu tutum, iş ve yaşam doyumu gösterilebilir. Ancak bunların da dışında rehberlerin en 
büyük beklentisi mesleklerini icra ederken karşılaştıkları sorunlara çözüm bulunmasıdır. $\mathrm{Bu}$ sorunların arasında seyahat acenteleri ve tur operatörleriyle ilgili sorunlar, rehberlik eğitimi, vergilendirme, sağlık güvencesi, çalışma kartı ücretleri, gölge rehberlik, mevsimlik iş yoğunluğu, iş güvencesi olmaması, haksız kazanç ve kaçak rehberlik sayılabilir. Rehberler bu sorunların çözülebilmesi, meslek yasalarında olan boşlukların giderilmesi için devletin desteğinin arkalarında olmasını beklemektedirler. Bu tip sorunları en aza indirgemek için de bakanlığa bağlı birimlerce denetimciler devreye girmektedir (Koçak \& Kabakulak, 2018: 2627). Turist rehberleri mesleği icra ederken gezdirdikleri bölge içerisinde oda, birlik ve bakanlık tarafından belirlenmiş denetimcilere denk gelebilmektedir. Rehberler bu denetimcilere istenilen evrakları göstermekle mükelleftir. Yapılan denetim sırasında tutulan tutanaklar ise bakanlık tarafından hazırlanan standart bir tutanaktır. Bir rehberin bu denetimler konusunda bilgisinin olması, meslek icrası ve mesleki olarak görevi bakımından oldukça önem arz etmektedir. Bu denetimlerin amacı, rehberlerin hak kaybının en aza indirilmesi ve meslek standartlarını korumaktır (Albuz, vd., 2018: 73-74).

\section{Alanyazinı Taraması}

$\mathrm{Bu}$ yapılan çalışmanın dışında 2018 yılı Nisan-Aralık ayları arasında TUREB denetleme görevlileri tarafından saha denetimleri gerçekleştirilmiştir. $\mathrm{Bu}$ denetimlerde "eylemsiz rehberlik, taban ücretin altında çalışma, bölge dışında rehberlik, belgesiz acentecilik faaliyeti, sözleşmesiz rehberlik hizmetinde bulunanlar" gibi 22 konu başlığı üzerinde durulmuştur. Elde edilen raporlarda ise belgesiz acentecilik faaliyeti, rehbersiz tur ve kaçak rehberlik yapma faaliyetleri diğer konu başlıklarına göre daha fazla sorun teşkil ettiği gözlemlenmiştir (TUREB, 2020). Ayrıca yapılan alanyazını taraması ile konuyla alakalı yayınlar yıl bazında aşağıda sıralanmıştır.

Çetin ve Kızılırmak (2012) ülkemizde çalışan kokartlı profesyonel turist rehberlerin hizmet durumlarını araştırmıştır. Elde ettikleri sonuca göre kaçak rehberlik faaliyetleri ile başa çıkmak için denetimlerin arttırılması gerekmektedir. Başka tedbirler arasında ise mevsimlik olan durumlarını tüm yıl faaliyetlerine yaymak, uzmanlık alanlarına göre eğitim verilmesi, mevcut analizlerin yapılarak nadir dillerde rehber yetiştirilmesi gibi maddeler vardır.

Zengin, Eker ve Bayram (2017) tarafından, 6326 sayılı Turist Rehberliği Meslek Kanunu ve bu yasaya bağlı çıkartılan Turist Rehberliği Meslek Yönetmeliğinin rehberlerin bakış açısıyla değerlendirilmesine yönelik bir çalışma yapılmışıtır. Bu çalışmanın sonucu olarak da 6326 sayılı kanunun yasal olarak rehberlik mesleğini bir statü kazandırdığg ancak bazı sorunları çözmede hala yetersiz kaldığını ortaya koymuştur. Bu sorunlar arasında en çok mağduriyet yaşanılan hususlar taban ücretin altında çalışma ve kaçak rehberlik konusudur. $\mathrm{Bu}$ sorunların giderilmesi için Meslek Kanunu'nun belirli aralıklarla gözden geçirilip revize edilmesi gibi birçok önerilerde bulunulmuştur.

Saatc1 ve Demirbulat (2018) 2017 yılına ait TUREB denetim raporlarının incelenmesini konu alan çalışma yapmışlardır. Bu çalışmalarında sonuç olarak denetim hususunda yetersizlik tespit etmişlerdir. Bu yetersizliklerden bazıları arasında Mersin, Denizli, Gaziantep, Diyarbakır vb. illerinde hiç denetim olmadığı görülmüştür. İlaveten kaçak rehberlik ve diğer yasadışı faaliyetlerin önüne geçilmesi için denetimlerin ve denetlenen gün sayılarının arttırılması önerilmiştir.

Çakmak (2019) yasa dışı rehberlik faaliyetlerinin hangi ülkelerin grup merkezli olduğu ve bu turlarda hangi tür rehberlik hizmetinin talep edilip, nerelerde yoğunlaştı̆̆ını bulmak için bir çalışma yapmıştır. Bu araştırmada sonuç olarak Ortadoğu ülkelerinden gelen 
turistlerin yasal profesyonel turist rehberleri yerine Suriye asıllı kaçak rehber ile özellikle İstanbul Tarihi Yarımada ve Adalar çevresinde tura çıktıkları görülmüştür.

1897 yllında gelir dağılımındaki adaletsizliği göstermek için İtalyan ekonomist Wilfredo Pareto tarafından geliştirilmiş olan ve 80-20 kuralı olarak da bilinen Pareto Analizi en basit tanımıyla sonuçların \%80'inin kaynă̆ının sebeplerin \%20'sine dayandığını öngörmektedir. Bir başka deyişle "Pareto Analizi" var olan sorunların içinden önceliklerin belirlenmesi konusunda karar verme sürecinde yardımcı araçlardan biridir. "Pareto Analizi" en önemli birkaç konu/sorun üzerine dikkatlerin toplanmasını ve önceliklerin belirlenmesini sağlar. Bu yönüyle verimlilik, pazarlama, satış analizi, kalite kontrol, stok analizi, satın alma ve atık azaltma süreçleri gibi üretim ve yönetim alanlarında kullanılmaktadır.

Literatüre bakıldığında, Özcan (2001) bu tekniği kullanarak, çimento sanayisinde bir uygulama geliştirmiş, Çakırkaya ve Acar (2016) ise bir üretim hattında meydana gelen hataların önem derecelerine göre belirlenmesi amacıyla pareto analizini kullanmıştır. Öte yandan deniz güvenliği uygulamalarından (Ziarati, 2006), Türkiye'de Öğretmenlik Mesleğinin Statüsünün analizine kadar geniş uygulama alanları bulmuştur (Ünsal, 2018).

\section{Yöntem}

$\mathrm{Bu}$ araştırma Türkiye Turist Rehberleri Birliği'nin (TUREB) web sitesinde yer alan istatistik bilgileri içinden 2019 y1lı içinde gerçekleştirilmiş olan denetim raporlarından elde edilen veriler üzerinden gerçekleştirilmiştir. Elde edilen denetim raporları "Pareto Analizi" denilen yöntem ile analiz edilmiştir. Bu yöntem farklı sayıda önem teşkil eden sebepleri, daha az önemde olanlardan ayırmak için kullanılır. Bu teknik, grafik yardımıyla gösterilmesi ve ortaya çıkan problemin ya da konunun en önemli sebebi üstüne dikkatini yoğunlaştırdığından ve önceliklerin belirlenmesinde önemli rolü olduğundan dolayı ekonominin dışında da kullanılabilir. Özellikle kalite kontrol ve geliştirme gibi durumlarda problem tespiti yapılırken hangi hataların daha büyük ve daha çok yüzdeye sahip olduğu bu teknik aracılığıyla kolaylıkla yapılmaktadır. ABC analizi olarak da bilinen Pareto grafiği, normal dağılımda sonuçların \%80'inin, sebeplerin \%20'sinden kaynaklanan ve literatürde bu duruma '80-20' kuralı da denilen formülle analiz edilmektedir (Özcan, 2001: 152-153).

\section{Bulgular}

$\mathrm{Bu}$ çalışmanın temel amaçlarından biri olan TUREB'in 2019 yılı içinde değişik il ve bölgelerde gerçekleştirmiş olduğu denetimler sonucu hazırladığı ve TUREB'in resmi web sitesindeki istatistik başlığı altında yayınladığı bilgilerden elde edilmiş olan veriler Tablo 1'deki gibidir.

Tablo 1'de görüleceği üzere, 2019 y1lı içinde toplam 1.317 adet denetleme gerçekleştirilmiştir. Bu denetlemelerin 264 adeti sadece Nisan ayında gerçekleştirilmiş olmasına rağmen takip eden aylarda bu rakamın çok altından yarıya yakın miktarda gerçekleştirildiği görülmektedir. Bu da sezon başlangıcı kabul edilen Nisan ayında tarafların denetim yapma konusunda azimli ve kararlı olmalarına rağmen sezonun başlamasıyla ile işlerin Nisan ayına göre çok daha fazla artmasına rağmen denetimlerde önemli oranda gevşeme gözlemlenmiştir. Haziran, Temmuz, Ağustos ve Eylül aylarında yapılan denetleme sayısı toplam denetlemelere oranla yaklaşık olarak 1/3 oranında gerçekleşmiştir. Oysa geçtiğimiz yıl turist istatistiklerine baktığımızda bu dönemde gelen turist sayısı yıllık toplam gelenlere oran $1 \% 50$ 'den her zaman fazla olmuştur. Turist sayısının yarıdan fazlasının geldiği bir dönemde sadece yapılması gereken denetimlerin üçte birinin gerçekleştirilmesi, sektörde oluşan/oluşabilecek olumsuz durum ve davranışların önüne geçilmesi konusunda zaaf 
Turist Rehberliği Dergisi (TURED) \& Y1l. 2020, Cilt. 3, Sayı. 2

Journal of Tour Guiding (JOTOG) \& Year. 2020, Volume. 3, Issue. 2

yaratacaktır. Bu dönemde yaşanan yoğunluk sebebiyle önceliklerin "Denetim" dışındaki alanlara kaydığı öngörülmektedir.

Tablo 1: 2019 Y1lı TUREB Verilerine Göre Yapılan Denetimlerin Genel Sayı ve Yüzdeleri

\begin{tabular}{|c|c|c|}
\hline Ay & Denetim Sayısı & Oran (\%) \\
\hline Ocak & 49 & 3,46 \\
\hline Subat & 54 & 3,81 \\
\hline Mart & 63 & 4,45 \\
\hline Nisan & 264 & 18,63 \\
\hline Mayıs & 101 & 7,13 \\
\hline Haziran & 81 & 5,72 \\
\hline Temmuz & 149 & 10,52 \\
\hline Ağustos & 141 & 9,95 \\
\hline Eylül & 144 & 10,16 \\
\hline Ekim & 135 & 9,53 \\
\hline Kasım & 112 & 7,90 \\
\hline Aralık & 124 & 8,75 \\
\hline Toplam & 1.417 & 100,00 \\
\hline
\end{tabular}

Tablo 2'de görüleceği üzere, 2019 yılında yapılan denetlemeler de 17 farklı konuda 1417 uygunsuzluk tespit edilmiş ve tutanak tutulmuştur. Yine Tablo 2 ve Grafik 1'den anlaşılacağı üzere 2019 yılında gerçekleştirilen denetlemelerde karşılaşılan en büyük kusur $472 \mathrm{kez}$ 'Belgesiz Acentecilik Faaliyetinde Bulunmak'ki bu da toplam denetlemelerin \%33'ünü oluşturmaktadır. İkinci sırada 386 kez "Rehbersiz Tur Faaliyeti” yer almakta olup, bu da toplam denetlemelerin \%27'sini oluşturmaktadır. Üçüncü sırada ise 274 kez ile 'Kaçak Rehberlik Faaliyeti' toplam denetlemelerdeki \%19 payıyla yer almaktadır. Bu ilk üç en çok ihlal edilen madde toplandığında, 1132 ihlal ve toplam denetlemelerin yaklaşık \%80'inini oluşturmaktadır. Yapılan denetlemelerde en az 1 kez ihlal edilen kural sayısı incelendiğinde değişik zamanlarda 1417 kez 17 farklı kuralın ihlal edildiği görülmektedir. Bu ihlal edilen 17 kuralın sadece üç tanesinde (yani yaklaşık \%18'lik bir kısmında) düzeltme yapıldığında toplam ihlallerin \%80'inin düzeltilmiş olması mümkün olacaktır. Dördüncü sırada ise "Acente Belge Eksikliği” ile ilgili 129 kez uygunsuzluk bulunmuş olup, bu uygunsuzlukta toplam uygunsuzluklara oranla \%9'unu oluşturmaktadır. Daha sonra sırasıyla; "Meslek İlkelerine Aykırı Davranışta Bulunan" 54 kez ve \%4, "Sözleşme Yapmadan Tur veya Paket Turda Rehberlik Yapan" 41 kez ile \%3, "Rehber Acente Sözleşmesi Yapmayan Seyahat Acentesi" $41 \mathrm{kez}$ ile \%2, "Rehberlik Sözleşmesi Yanında Bulunmayan" $12 \mathrm{kez}$ ile \%1 ve "Diğer"lerinde ise $29 \mathrm{kez}$ ile $\% 2$ 'lik bir paya sahiptir. 
Turist Rehberliği Dergisi (TURED) \& Y1l. 2020, Cilt. 3, Sayı. 2

Journal of Tour Guiding (JOTOG) \& Year. 2020, Volume. 3, Issue. 2

Tablo 2: 2019 Yı1ı TUREB Verilerine Göre Yapılan Denetimlerin Tutanak Sonuçları 2019 Denetim Raporu İcmali

6326 sayılı Meslek Kanununun 7. Maddesi ve Turist Rehberliği Yönetmeliğinin 41. Maddesi gereğince, 01 Ocak-31 Aralık 2019 tarihleri arasında TUREB denetmenleri tarafından odaların yetki çevresinde gerçekleştirilen denetimlerde tutulan tutanak sayıları aşağıdaki gibidir.

\begin{tabular}{|c|c|c|c|}
\hline S. No & Tutanak Konusu & Miktarı & $\%$ \\
\hline 1 & $\begin{array}{l}\text { Belgesiz Acentecilik Faaliyetinde Bulunan (İl Kül. Tur. Md.lüğü } \\
\text { tarafından Tanzim) }\end{array}$ & 472 & 33,31 \\
\hline 2 & Rehbersiz Tur Faaliyeti (İl Kültür Turizm Md.lüğü Tarafından Tanzim) & 386 & 27,24 \\
\hline 3 & Belgesiz (Kaçak) Rehberlik Faaliyetinde Bulunan & 274 & 19,34 \\
\hline 4 & Belge Eksikliği (Acente) & 129 & 9,10 \\
\hline 5 & Meslek İlkelerine Aykırı Davranışta Bulunan & 54 & 3,81 \\
\hline 6 & Sözleşme Yapmadan Tur veya Paket Turda Rehberlik Yapan & 41 & 2,89 \\
\hline 7 & Rehber Acente Sözleşmesi Yapmayan Seyahat Acentesi & 20 & 1,41 \\
\hline 8 & Rehberlik Sözleşmesini Yanında Bulundurmayan & 12 & 0,85 \\
\hline 9 & Çalışma Kartını Yanında Bulundurmayan & 8 & 0,56 \\
\hline 10 & Görevlilere Bilgi ve Belge Vermeyen/Yalan, Eksik Beyanda Bulunan & 5 & 0,35 \\
\hline 11 & Bölgesi Dışında Çalışan & 4 & 0,28 \\
\hline 12 & İş Taahhüdüne Aykırı Çalışan & 3 & 0,21 \\
\hline 13 & $\begin{array}{l}2018 \text { Yılı Çalışma Kartı Olmadan Rehberlik Faaliyeti Yapan (Eylemsiz } \\
\text { Rehber) }\end{array}$ & 2 & 0,14 \\
\hline 14 & Taban Ücretin Altında Çalışan & 2 & 0,14 \\
\hline 15 & Dili Dişında Çalışan & 2 & 0,14 \\
\hline 16 & Tüketicinin Yanıltılması & 2 & 0,14 \\
\hline 17 & Çalışma Kartını Görünür Şekilde Taşımayan & 1 & 0,07 \\
\hline 18 & Meslek Kuruluşları /Turizme Zarar Verici Söz veya Davranışta Bulunan & 0 & 0,00 \\
\hline 19 & $\begin{array}{l}\text { Ülke Yararına ve Milli Onura Aykırı Hareket, Söz veya Davranışta } \\
\text { Bulunan }\end{array}$ & 0 & 0,00 \\
\hline 20 & Gruplara Zarar Veren & 0 & 0,00 \\
\hline 21 & Yasa Dışı Çalışan Yabancı (Kolluk tarafından Tanzim) & 0 & 0,00 \\
\hline 22 & Alan Kılavuzluğu ile ilgili çalışma & 0 & 0,00 \\
\hline & TOPLAM & 1417 & 100,00 \\
\hline
\end{tabular}

Ayrıca gerçekleştirilen bu denetimlerin tümünde, "Meslek Kuruluşları/Turizme Zarar Verici Söz veya Davranışta Bulunma”, "Ülke Yararına ve Milli Onura Aykırı Hareket, Söz veya Davranışta Bulunma", "Gruplara Zarar Verme', "Yasadışı Çalışan Yabancı" ve "Alan Kılavuzluğu ile ilgili Çalışma" konularında herhangi bir uygunsuzluk ve uyumsuzluk olmaması sebebiyle herhangi bir denetim tutanağı tutulmamıştır. $\mathrm{Bu}$ yönüyle bu beş maddedeki durumlar hakkında olumsuz bir durum oluşmamış olması sevindiricidir. $\mathrm{Bu}$ yönüyle yapılan "Pareto Analizi"ne bu beş madde dahil edilmemiş olup, toplam 17 kategori üzerinden değerlendirilmesi yapılmıştır. 
Turist Rehberliği Dergisi (TURED) \& Y1l. 2020, Cilt. 3, Sayı. 2

Journal of Tour Guiding (JOTOG) \& Year. 2020, Volume. 3, Issue. 2

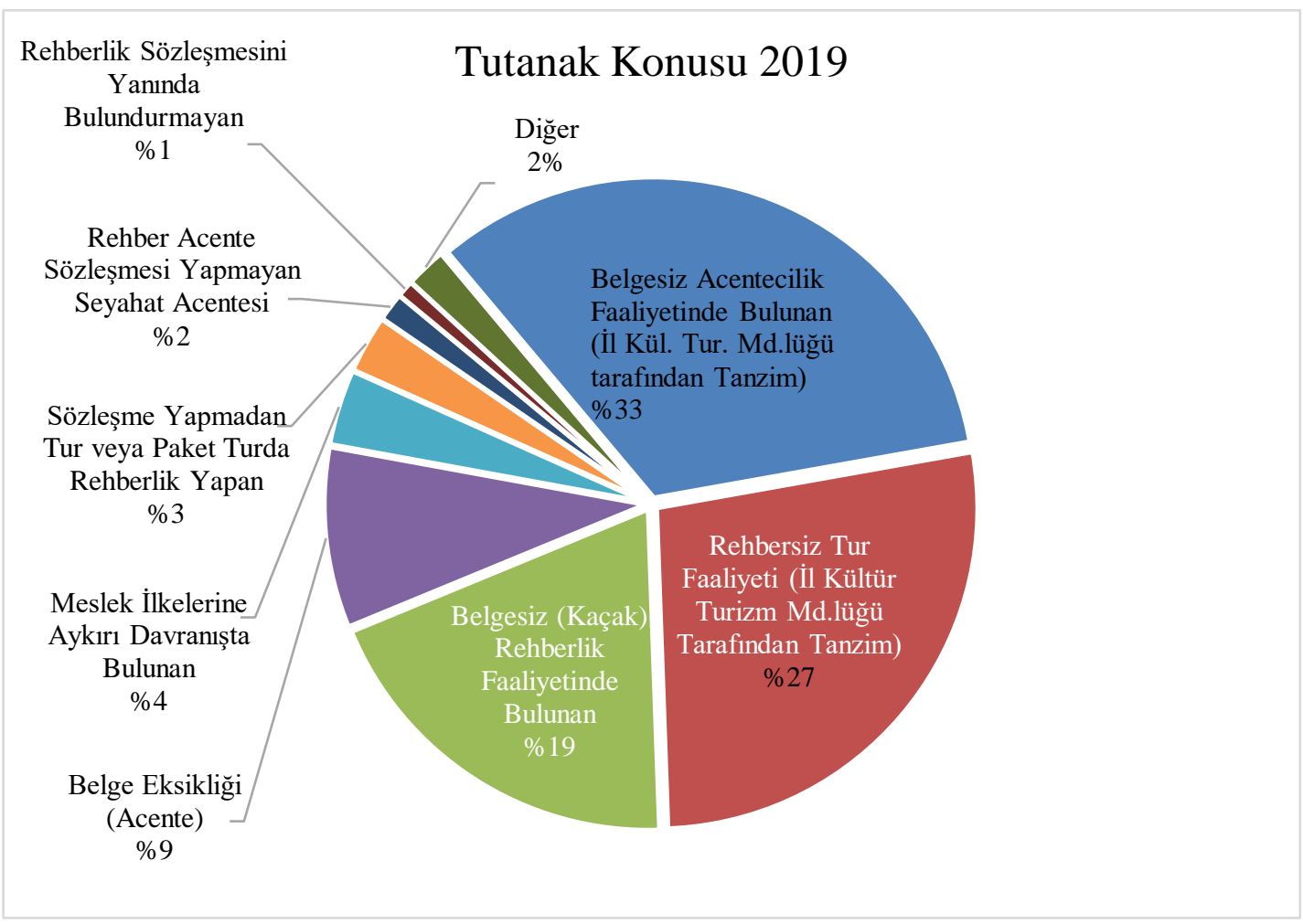

Grafik 1: 2019 Yı1ı TUREB Verilerine Göre Yapılan Denetimlerin Tutanaklarının Grafiksel Olarak Sonuçları

\section{Sonuç ve Öneriler}

Turist rehberliği mesleği turizmde önce gelen meslekler arasında gösterilmektedir. $\mathrm{Bu}$ mesleğin denetlenmesi ve ortaya çıkartılan sorunlara çözüm bulunması da mesleğe olan önemi arttıracak olup, daha nitelikli bir hizmet verilmesini sağlayacaktır. 1897'de İtalyan ekonomist Wilfredo Pareto tarafından geliştirilen ve ülkelerdeki gelir dağılımının eşit olmadığını göstermek amacıyla formüle ettiği halk arasında 80'e 20 kuralı olarak da bilinen Pareto Analizi başta iktisadi konular için geliştirdiği bu teorinin yapısı gereği gerek sosyal bilimlerde gerekse diğer alanlarda da kendine kullanım alanı bulmuştur. Özetle 'sonuçların \%80'inin, sebeplerin $\% 20$ sinden kaynaklanmaktadır' şeklinde formüle edebileceğimiz bu analiz yöntemi, yukarıda vermiş olduğumuz verilere uygulandığında da \%100 e yakın bir uyum sağlamaktadır.

Tablo 3: 2019 Yı1ı TUREB Verilerine Göre Yapılan Denetimlere Ait Tutulan En Çok İlk 3 Tutanak Konusu

\begin{tabular}{|c|l|c|c|}
\hline S. No & Tutanak Konusu & Miktarı & \% \\
\hline $\mathbf{1}$ & $\begin{array}{l}\text { Belgesiz Acentecilik Faaliyetinde Bulunan (İl Kül. Tur. Md.lüğü tarafından } \\
\text { Tanzim) }\end{array}$ & 472 & 33,31 \\
\hline $\mathbf{2}$ & Rehbersiz Tur Faaliyeti (İl Kültür Turizm Md.lüğü Tarafından Tanzim) & 386 & 27,24 \\
\hline $\mathbf{3}$ & Belgesiz (Kaçak) Rehberlik Faaliyetinde Bulunan & 274 & 19,34 \\
\hline & TOPLAM & $\mathbf{1 1 3 2}$ & $\mathbf{7 9 , 8 9}$ \\
\hline
\end{tabular}


Buna göre; Tablo 2'de gösterilen veriler ışı̆̆ında 17 farklı kategoride denetleme gerçekleştirilmiştir. Bu 17 kategorinin \%20'sini hesapladığımız da 17 x0,20 = 3,4 yaklaşık olarak üç tane kategori olarak karşımıza çıkmaktadır. Bu elde edilen 3 kategori sayısı en çok denetleme sonucu tutanak tutulan ilk üç kategorinin tutanak toplam sayıları hesaplandığında; 1132 tutanakla toplam tutanakların yaklaşık \%80'inini kapsadığı görülmektedir. Bu kapsama bakıldığında da "Belgesiz Acentecilik Faaliyetinde Bulunma" konusunun ihlalinin ilk olarak öne çıktığı görülmektedir. Sonrasını takiben sırasıyla "Rehbersiz Tur Faaliyeti" ve "Belgesiz (Kaçak) Rehberlik Faaliyetinde Bulunma" konusunun ihlalinin geldiği dikkat çekmektedir. Böylelikle bu konuların Turist Rehberliği mesleği için en büyük tehdit olduğu da ortaya çıkmıştır. Bu sebeple, bu denetimleri gerçekleştiren TUREB yetkililerine aşağıdaki maddeler önerilmektedir.

Konunun diğer tarafı olan TÜRSAB ile oluşturulacak altyapı, eğitim ve yoğun denetimler ile "Belgesiz Acentecilik Faaliyetleri", "Turların Rehbersiz Olarak Düzenlenmesi" ve "Kaçak Rehberlik" faaliyetlerinin etkin bir şekilde önlenmesi durumunda var olan sorunların \%80'ini halletmek mümkün olabilir.

Yapılan denetimlerin etkin bir şekilde yapılabilmesi için sadece sezon öncesi dönemde arttırılarak değil, yılın 12 ayına yayılan bir denetim anlayışı ile denetimler gerçekleştirilebilir ve özellikle yoğun turist girişlerinin olduğu, haziran, temmuz, ağustos ve eylül aylarında bu denetimler gelen turist sayısı ile senkronize bir şekilde arttırılabilir.

Ayrıca dördüncü büyük denetim eksiği olarak görülen "Acente Belge Eksikliğì" konusu da yine konunun partneri konumunda olan TÜRSAB ile görüşülerek, acentelere bu konunun etkin bir şekilde duyurulması ve ihtiyaç varsa bu konuda eğitimler düzenlenmesi gerekebilir.

"Meslek İlkelerine Aykırı Davranış" yapılan denetimlerde 54 tutanak ile beşinci büyük grubu oluşturmaktadır. Bu da TUREB'in gerek kendi açtığ 1 sertifika programlarında gerekse üniversitelerde Turist Rehberliği bölümünde okuyan öğrencilere yönelik "Meslek Etiği” konulu dersler verilebilir.

Altınc1, yedinci ve sekizinci maddeler de yer alan durumlar genellikle ya acentenin rehber sözleşmesini yapmamasından ya da rehberin sözleşmesiz çalışmasından veyahut yapılan bu sözleşmenin rehber yanında bulunmamasından kaynaklı konular olup, bu üç maddeden oluşan toplam uygunsuzluk, 73 gibi oldukça yüksek bir sayıdır. Oysa mevcut 6326 sayılı Meslek Kanunu ve 29217 sayılı Turist Rehberliği Meslek Yönetmeliği bu sözleşme ile ilgili birçok uygulama esnekliği ve kolaylığ getirmiş̧ir. Şöyle ki; "yönetmelik maddesi gereğince ve tur esnasında yapılacak denetimlerde mağdur olunmamasını teminen sözleşme tarafları için haklı nedenlerin bulunduğu hâllerde 'geçerli mazeretleri sona erdiği tarihten itibaren en geç yedi gün içinde, yazılı olarak düzenlenmek kaydıyla e-posta, faks, telefon mesajı ve benzeri yollarla sözleşme yapılabileceklerdir" denmektedir. Denetlemelerde bu konuda 73 adet uygunsuzluğun bulunması bu konunun taraflarca yeteri kadar anlaşılmadığını ortaya koymaktadır. Yukarıdaki diğer maddeler de olduğu gibi bu konuların da TÜRSAB ile hareket ederek gerek rehberlerin gerekse seyahat acentelerin bilinçlendirilmesi sağlanabilir.

Elde edilen denetim raporları aylık bazda yapılan denetimler ve yapıldığı iller/bölgeler belirtilerek hazırlanmasına rağmen hangi uygunsuzluğun en çok hangi bölge de yapılan denetimlerde ortaya çıktığını bu verilerden elde etmek mümkün değildir. Bu sebeple TUREB'in aylık olarak yaptığı bu ve yayınladığ 1 bu denetim raporlarının detaylarını gösteren, hangi uygunsuzluğun hangi bölge denetimlerinde gerçekleştiğini gösterir bilgiler içermesi, hem yaşanan bu olumsuz durumların bölge kaynaklı etkisinin tespit etmek, hem de daha yoğun 
Turist Rehberliği Dergisi (TURED) \& Y1l. 2020, Cilt. 3, Sayı. 2

Journal of Tour Guiding (JOTOG) \& Year. 2020, Volume. 3, Issue. 2

sorun yaşanan bölgeler öncelikle olmak üzere düzeltme faaliyetlerine başlamak için daha doğru bir yol izlenmesi mümkün olabilecektir.

Sektörde icra ettikleri fonksiyonlar gereği, zaman zaman rakip gibi gözükmekte olsalar bile, yaşanan bu denetim eksiklikleri TUREB ile TÜRSAB'ın birlikte her türlü rekabet ve yıkıcı faaliyetten uzak \%100 bir işbirliğinin zorunluluğunu ortaya koymaktadır. Bu sebeple gerek TUREB gerekse TÜRSAB'ın üyeleri arasından ve bakanlık temsilcilerinin de bulunduğu ortak bir 'Denetim Komisyonu' kurulması ve ülke çapında tüm denetimlerin bu kurula bağlı kişi ya da kişilerce yapılması oluşan olumsuzluklarla mücadele de etkili olabilir. Ayrıca denetim esnasında oluşabilecek tartışma ve yanlış anlaşılmaların da önüne geçilmesi sağlanabilecektir. Bu "Denetim Komisyonu" görev icabı her iki kuruma karşı görevlendirme açısından sorumlulukları olmasına rağmen direkt 'Kültür ve Turizm Bakanlığına Bağlı' olarak çalışabilir ve bağımsız bir fonksiyon icra edebilir.

Yapılan bu denetimler sonucu elde edilen olumsuz durumlar her ne kadar TUREB ya da TÜRSAB'1 etkiler gibi gözükse de burada yaşanan tüm sorunlar işin asıl sahibi olan turistleri etkilemekte ve zaman zaman bu eksiklikler sebebiyle mağdur olmaktadır. $\mathrm{Bu}$ mağduriyetin önüne geçmek için yurt çapında 'Kaçak Tur ve Rehberlik' faaliyetleri başta olmak üzere bu hizmeti alanların haklarını öğretmek amacıyla ülke çapında bir bilinçlendirme kampanyası, bakanlık, TUREB ve TÜRSAB ile gerçekleştirilebilir. Böylelikle bilinçli tüketicinin varlığı ona hizmet verenlerin de otomatik olarak bilinçlenmesine ve yüzde yüz yasa ve kurallara göre hareket etmesine sebep olabilir.

\section{Kaynakça}

Albuz, N., Çakmak, T.F., Eren, A., Tekin Ö. \& Yeşildağ, G.N.G. (2018). Turist Rehberliğine Giriş, Detay Yayıncılık, Ankara.

Arat, T. \& Bulut, H. Ç (2019). Turist Memnuniyetinde Turist Rehberinin Rolü: Konya'da Bir Araştırma. Turist Rehberliği Dergisi (TURED), 2(1), 31-43.

Avcı, E. \& Doğan, S. (2018). E-Şikâyetler Turist Rehberleri Hakkında Ne Söylüyor?. Seyahat ve Otel Işsletmeciliği Dergisi, 15(1), 133-148.

Cansu, E. \& Bahadır, U. (2019). Seyahat Acenteleri Tarafından Yurtiçi Paket Turlarda Uygulanan Satış Teknikleri Üzerine Bir Araştırma, İstanbul İli Örneği. Türk Turizm Araştırmaları Dergisi, 3(4), 920-930.

Çakırkaya, M. \& Acar, Ö.E. (2016). Bir Üretim Hattında Meydana Gelen Hataların Önem Derecelerinin İstatistiksel Proses Kontrol Tekniklerinden Pareto Analizi ile Belirlenmesi, Mustafa Kemal Üniversitesi Sosyal Bilimler Enstitüsü Dergisi, 13(36) 272-288.

Çakmak, T. F. (2019). Yasa Dışı Rehberlik Faaliyetlerinin Denetlenmesi: İstanbul Rehberler Odası Örneği, Turizm Akademik Dergisi, 6(2), 31-41.

Çetin, G. \& Kizılırmak, İ. (2012). Türk Turizminde Kokartlı Turist Rehberlerin Mevcut Durumunun Analizi. Afyon Kocatepe Üniversitesi İktisadi ve İdari Bilimler Fakültesi Dergisi, 14(2), 307-318.

Çınar, B. \& Yenipınar, U. (2019). Turizm Rehberliği Bölümü Öğrencilerinde Genel Öz Yeterlilik Algısı, Mesleki Kaygı ve Mesleği Yapma Niyeti İlişkisi. Anatolia: Turizm Araştırmaları Dergisi, 30(3), 153-162.

İrigüler, F. \& Güler, M. E. (2016). Tourist Guiding: "Cinderella" of The Tourism, İçinde: Global Issues and Trends in Tourism, (Ed: C. Avcıkurt, M.S. Dinu, N.Hacıŏlu, E.Efe, A.Soykan \& N.Tekik). 203-220. Sofia: St. Kliment Ohridski University Press,

İşçeli, Z. \& Kılıç, G. (2018). Lisans Düzeyinde Turizm Rehberliği Eğitimi Veren Fakültelerin Müfredatlarının İncelenmesi. Turist Rehberlĭgi Dergisi (TURED), 1(1), 41-56. 
Turist Rehberliği Dergisi (TURED) \& Y1l. 2020, Cilt. 3, Sayı. 2

Journal of Tour Guiding (JOTOG) \& Year. 2020, Volume. 3, Issue. 2

Koçak, B. \& Kabakulak, A. (2018). Turist Rehberlerinin Meslekten Beklentileri Üzerine Bir Araştırma. Turist Rehberliği Dergisi (TURED), 1(1), 24-30.

Özcan, S. (2001). İstatistiksel Proses Kontrol Tekniklerinden Pareto Analizi ve Çimento Sanayiinde Bir Uygulama. Cumhuriyet Üniversitesi İktisadi ve İdari Bilimler Dergisi, 2(2), 151-174.

Pelit, E. \& Katırcıoğlu, E. (2018). Turist Rehberliği Mesleğinde Taraflar Açısından Yaşanan Sorunlar Üzerine Bir Değerlendirme. Turist Rehberliği Dergisi (TURED), 1(2), 74-94.

Saatc1, G. \& Demirbulat, Ö.G. (2018) Turist Rehberleri Birliği'nin (TUREB) 2017 Y11 Denetim Raporlarının İncelenmesi: Turist Rehberliği Üzerine Güncel Araştırmalar, (Ed: Hacıoğlu, N., Avcıkurt, C., Kılıç, A. \& Yıldırım, H.U). 567-665. Ankara: Detay Yayıncılık.

Tătar, C. F., Herman, G. V. \& Gozner, M. (2018). Tourist Guides' Contribution to Sustainability in Romania. Geojournal of Tourism and Geosites, 21(1), 282-287.

Turist Rehberliği $\quad$ Meslek Kanunu. https://www.resmigazete.gov.tr/eskiler/2012/06/20120622-2.htm. Erişim Tarihi: 26.01.2020.

Turist Rehberliği Meslek Yönetmeliği. (2014). https://teftis.ktb.gov.tr/tr-120445/turistrehberligi-meslek-yonetmeligi.html (Erişim Tarihi: 26.01.2020)

Türkiye Turist Rehberleri Birliği (TUREB). (2020). http://www.tureb.org.tr/tr/page/detail/96 (Erişim Tarihi: 26.01.2020).

Ünsal, S. (2018). Türkiye'de Öğretmenlik Mesleğinin Statüsüne İlişkin Bir Pareto Analizi, Sakarya University Journal of Education, 8(2) 111-130.

Yenipınar, U. \& Zorkirişci, A. (2013). Türkiye ve Avrupa Birliği Ülkelerinde Turist Rehberliği Eğitimi. Çağ Üniversitesi Sosyal Bilimler Dergisi, 10(2), 111-136.

Zengin, B., Eker, N. \& Bayram, G.E. (2017). Turist Rehberliği Meslek Kanununun Profesyonel Turist Rehberlerince Değerlendirilmesi. Seyahat ve Otel işletmeciliği Dergisi, 14(2), 142-156.

Ziarati, R. (2006). Safety At Sea-Applying Pareto Analysis. In Proceedings of World Maritime Technology Conference (WMTC 06), Vol. 94, London, England, 2006.

WFTGA. (2020). http://www.wftga.org/tourist-guiding/what-tourist-guide (Erişim Tarihi: 26.01.2020).

\section{ETIKK ve BILIMSEL ILKELER SORUMLULUK BEYANI}

Bu çalışmanın tüm hazırlanma süreçlerinde (veri toplama, yazım vb.), tüm etik kurallara ve bilimsel atıf gösterme ilkelerine riayet edildiğini, herhangi bir hataya mahal vermemek için yayımdan önce makalenin bir intihal programı aracıllğıyla da kontrol edildiğini yazarlar beyan eder. Ayrıca yazarlar aşağıda sıralanan hususları kabul etmiştir:

1. Çalışmada yer alan ve kullanılan tüm kaynaklara, bilimsel araştırma yöntemleri ve etik ilkeler doğrultusunda atıf yapılmıştır.

2. Çalışmada tüm yazarların akademik-bilimsel olarak doğrudan ve ortak katkısı vardır.

3. Bu çalışma, yazarların özgün bir çalışmasıdır.

4. Bütün yazarlar dergiye gönderilen makaleyi görmüș ve sonuçlarını onaylamıștır.

5. Çalışmada kullanılan denek/deneklere ilişkin herhangi bir etik ihlal yapılmamış, kullanılan tüm veri toplama yöntemlerinde bilimsel etik ilkelere göre hareket edilmiştir.

6. Calıșma daha önceden bilimsel bir toplantıda sunulan özet veya bu çalıșmanın daha kısa hali ise, makalede bu durum belirtilmiştir.

7. Çalıșmada, hiçbir suç unsuru veya kanuna aykırı ifade bulunmamakla birlikte, araştırma yapılırken kanuna aykırı herhangi bir yöntem kullanılmamış olup, çalışma ile ilgili tüm yasal izinler alınmış ve etik kurallara uygun hareket edilmiştir.

Aksi bir durumun tespiti halinde Turist Rehberliği Dergisi'nin hiçbir sorumluluğu olmayıp, tüm sorumluluk makale yazarlarına aittir.

Tarih $\quad: 08 / 11 / 2020$

Sorumlu Yazar $\quad$ : Emrullah CANSU

Bahar ve Cansu; Turist Rehberliği Saha Denetlemelerinde Karşılaşılan Uygunsuzlukların Önceliklerinin Pareto Analizi ile Belirlenmesi / Determining the Priorities of Nonconformities Encountered in Tourist Guidance

Field Inspections by Pareto Analysis 